\title{
ANTIPLATELET ACTIVITY OF 2-OXINDOLE DERIVATIVES EXHIBITING GSK-3B INHIBITORY ACTIVITY
}

\section{E. Othman}

Department of Pharmacology and Bioinformatics, Volgograd State Medical University, Ministry of Health of Russia, 400001, Russia, Volgograd, st. KIM, 20.

DOI: 10.19163/MedChemRussia2021-2021-364

E-mail: elias.othman89@gmail.com

It is estimated that by 2030, 23.6 million people will die from cardiovascular disease per year. The key link in the development of these pathologies are disorders in the vascular-platelet hemostasis system. Previous studies have shown that new 2-oxindole derivatives have inhibitory activity against the GSK-3b enzyme. With the participation of this enzyme, there is a negative regulation of glycogenesis and the processes of activation and aggregation of platelets. It has been shown that heterocyclic nitrogen-containing compounds exhibit a wide range of pharmacological activity, including antiplatelet activity.
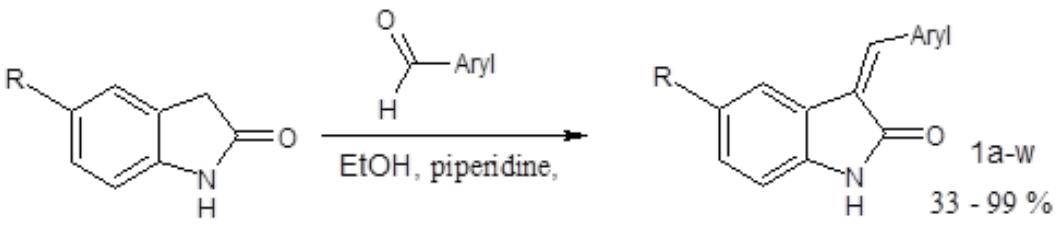

This study allows us to conclude that a new class of 2-oxindole derivatives is promising for the search for new inhibitors of platelet aggregation. Among the studied compounds, molecules were identified-K-165, K-167, K-215 and K-248, which exceeded the reference drug acetylsalicylic acid in terms of the level of antiplatelet activity (IC50) by 6, 10, 9 and 4.5 times, respectively. Also, molecules have been found that are highly active against the collagen-induced platelet aggregation process. Compounds under the code $\mathrm{KL}-4$ and $\mathrm{KL}-9$ showed the greatest activity in relation to the inhibition of these processes with an IC50 value of 7.4 and $6.4 \mu \mathrm{M}$, respectively. Under the action of collagen in high concentrations on platelets, platelet activation processes occur, mediated by interaction with glycoprotein VI receptors. In the signaling pathway from this receptor, the leading role is played by the enzyme GSK$3 \mathrm{~b}$, which positively regulates the processes of thrombus stabilization.

\section{References}

[1] E.V. Zaryanova, N. A. Lozinskaya, O. V. Beznos, M.S. Volkova, N.B. Chesnokova, N.S. Zefirov, Bioorg. and Med. Chem. Lett., 2017, 22, 3787-3793.

[2] Vilahur G., Gutiérrez M., Arzanauskaite M. etc. Vascul. Pharmacol. 2018. P. 22-25.

[3] Ishmetova R.I., Babkov D.A., Kucheryavenko A.F. and other Bulletin of the Academy of Sciences. Chemical series. 2020. No. 4. S. 768-773.

[4] Kucheryavenko A.F., Salaznikova O.A., Sirotenko V.S. and other Questions of biological, medical and pharmaceutical chemistry. 2015. No. 8. S. 9-13. 